\title{
PETROGENETIC INTERPRETATION OF GRANITOID ROCKS USING MULTICATIONIC PARAMETERS IN THE SANGGAU AREA, KALIMANTAN ISLAND, INDONESIA
}

\author{
Kyaw Linn Zaw ${ }^{* 1,2}$, Lucas Donny Setijadji ${ }^{1}$, I Wayan Warmada ${ }^{1}$, and Koichiro Watanabe ${ }^{3}$ \\ ${ }^{1}$ Department of Geological Engineering, Gadjah Mada University, Yogyakarta, Indonesia \\ ${ }^{2}$ Department of Geology, Yangon University, Myanmar \\ ${ }^{3}$ Department of Earth Resources Engineering, Kyushu University, Japan
}

\begin{abstract}
Granitoid rock compositions from a range of tectonic environments are plotted on a multicationic diagram, based on major and trace element geochemistry and $\mathrm{K}-\mathrm{Ar}$ dating. This shows that there is a different tectonic nature, rock affinity and suites. The basement granitoid rocks are ranging from diorite to granite composition. They appear to the products of crystallization differentiation of a calc-alkaline magma of island affinity and range to metaluminous granites, granodiorite and tonalite. The tectonic setting has two kinds which are subduction and post-subduction. The geochemical interpretation, origin and melting of mechanism and tectonic setting shows the types of granitoid are $M$ and $I-M$ type. The basement of granite and granodiorite are a segment of island arc that were happened the Sintang Intrusion as post subduction or syn-collision tectonic setting.
\end{abstract}

Keywords: Petrogenetic, tectonic, affinity, Sintang Intrusion, Kalimantan

\section{Introduction}

Sanggau area is located in the northwest part of West Kalimantan Province. The island of Kalimantan presently lies upon the southeast-

${ }^{*}$ Corresponding author: K.L. ZAW, Department of Geological Engineering, Faculty of Engineering, Gadjah Mada University, Jl. Grafika 2 Yogyakarta, 55281, Indonesia. E-mail: klinzaw@gmail.com ern margin of the greater Eurasian plate. It is bounded to the north by the South China Sea marginal oceanic basin, to the east by the Philippine Mobile Belt and the Philippine Sea Plate and to the south by the Banda and Sunda arc systems (Figure 1). It is bounded to the west by the Sunda Shelf and ultimately by Paleozoic and Mesozoic continental crust of the Malay Peninsula. The Greater Kalimantan Block is surrounded to the north, east, and south by plate boundaries and arc systems which are presently active or which have been active during the Tertiary and it is bounded to the west by an underexplored shelf region which possibly conceals a terrain boundary.

Based on petrological and geochemical characteristics such as rock assemblage, petrogeochemistry, K-Ar age, studied petrogenesis of different stages of magmatism of the granitic rocks from the Sanggau Area in Kalimantan. The magmatic activities of the Sanggau area can be divided into three stages. The Mesozoic magmatism, induced by northern subduction of The Paleocene-Eocene magmatism was the most intensive, and resulted from a complex progress of Neotethyan oceanic slab, including subduction, rollback, and subsequent breakoff. Neotethyan slab, was continuously developed, with two peak periods of Late Jurassic and Early Cretaceous.

And the Oligocene-Miocene magmatism was 


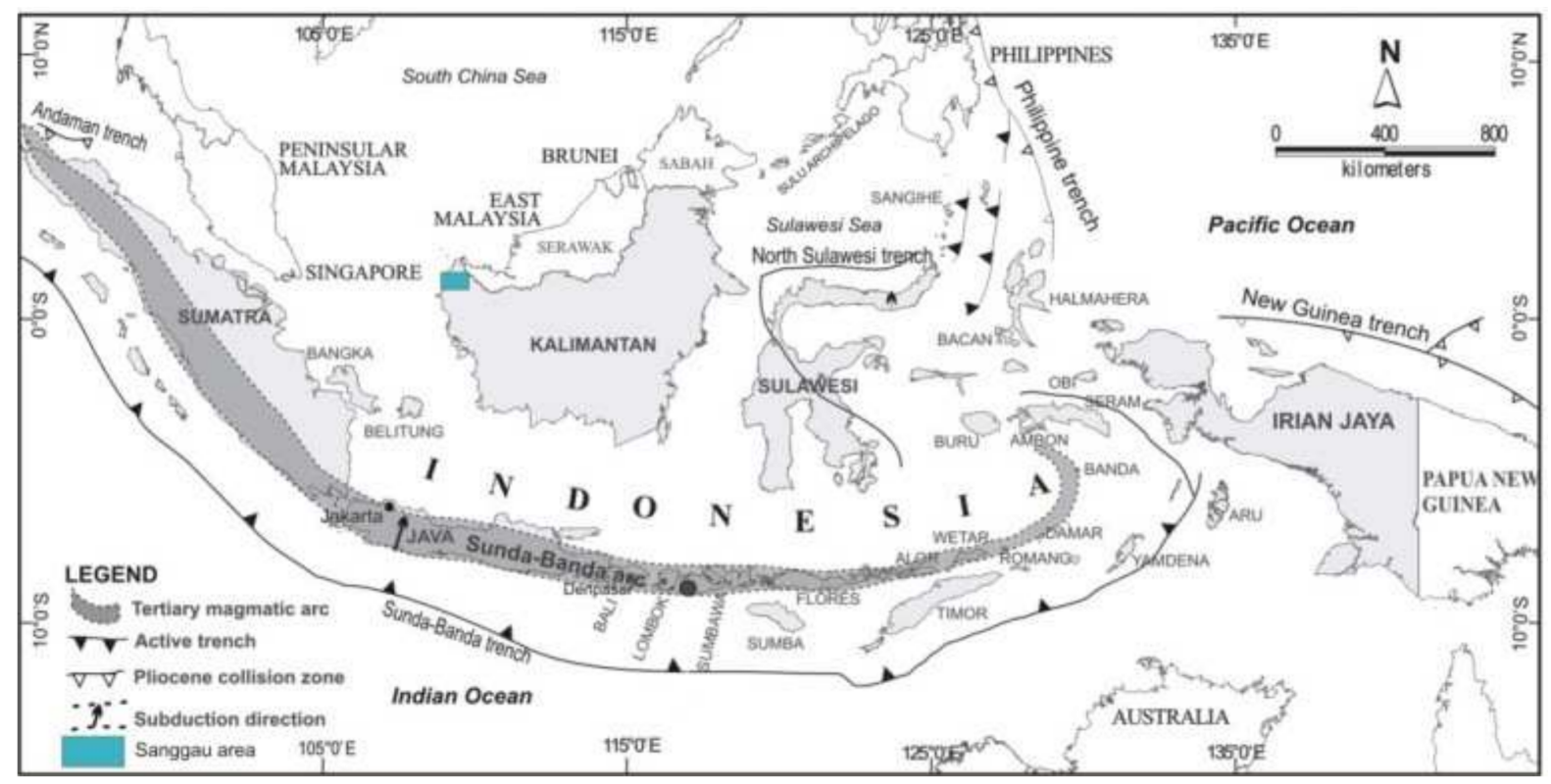

Figure 1: Location map and tectonic features of the Indonesia

attributed to the convective removal of thickened lithosphere in an east-west extension setting after India and Asia.

\section{REGIONAL GEOLOGICAL SET- TING}

The main elements of regional structure in West and Central Kalimantan and Sarawak are the huge prism of upper Cretaceous to lower Tertiary greywacke in the north, and the Lower to Upper Cretaceous subductionrelated Schwaner Batholith in the south. The western part of this region is formed by preTertiary igneous, metamorphic, and deformed sedimentary rocks (Figure 2), which constitute the Northwest Kalimantan Domain of William et al. (1988). The Semitau ridge is the most important structural feature in Sanggau. It is an east-southeasterly trending structural ridge spanning outcrops of Permo-Triassic foliated igneous rocks of the Busang Complex in the east and Embuoi Complex in Sanggau (Doutche, 1992). The huge Schwaner Batholith and its northwestern extension, the Singkawang Batholith (Amiruddin, 1989), appear to be confined to the southern side of the fundamental structure forming the Semitau ridge. The Semitau ridge parallels the northern margins of the granodiorite and tonalite of the Schwaner Batholiths, which in turn are considered to reflect the trend of a subduction zone active in Early Cretaceous times. The structural development of Sanggau was probably initiated in Triassic times with the subductionrelated deformation of the igneous rocks of the Embuoi Complex, as recorded by K-Ar ages on biotite from foliated granitoids. The prevailing regional trend preserved in all these formations is west-northwesterly, which together with the orientation of belts of mélange in adjacent Sheet areas reflects a convergent continental margin with the same orientation. Along this margin, which was probably located to the south of Sanggau deformation and accretion occurred intermittently from Triassic until early Tertiary times.

\section{GEOCHEMISTRY}

\section{Major elements}

The numbers of schemes based on chemical composition have been applied for the classification and nomenclature of igneous rocks. The classification scheme of De La Roche et al. (1980) involving the whole rock chemical composition into cation 


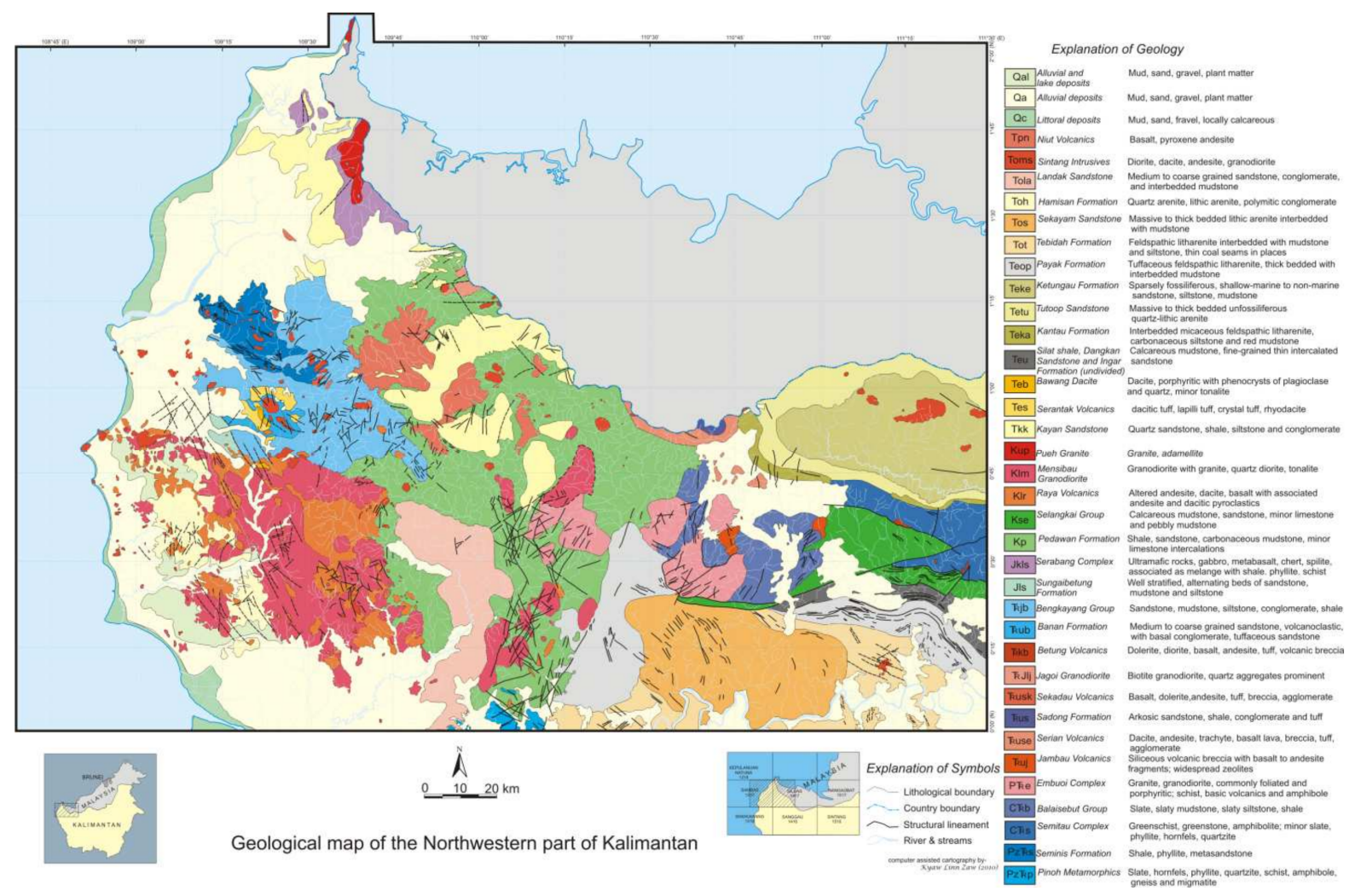

Figure 2: Regional geological map of the area

proportions yields mixed result. The regrouping of cations is such that the $\mathrm{X}$-axis, $\left[\mathrm{R}_{1}=4 \mathrm{Si}-11(\mathrm{Na}+\mathrm{K})-2(\mathrm{Fe}+\mathrm{Ti})\right]$, of the diagram portrays variation in quartz content while the Y-axis, $\left[\mathrm{R}_{2}=6 \mathrm{Ca}+2(\mathrm{Mg}+\mathrm{Al})\right]$, portrays variation in $\mathrm{Mg} / \mathrm{Fe}$ ratio and $\mathrm{An}$ content of the constituent plagioclase. For basic rocks with common assemblage plagioclase, pyroxene, and olivine, this classification scheme portrays their composition satisfactory. However, for basic and intermediate rocks containing cumulus amphibole, the $\mathrm{R}_{2}$ becomes unrealistically high, resulting in the classification of gabbroic rocks as ultrabasic and those of diorites as gabbros. In this scheme, the analyzed samples of the area plot closely; three in the field of granodiorites, tonalite and diorite (Figure 3).

On $\mathrm{SiO}_{2}$ vs. $\mathrm{Na}_{2} \mathrm{O}+\mathrm{K}_{2} \mathrm{O}$ classification scheme of Cox et al. (1979), the basement samples as granite, granodiorite and diorite (Figure 4). In O'Connor's (1965) normative An-Ab-Or diagram, the rocks plot in the field of tonalite, granodiorite and granite (Figure 5).

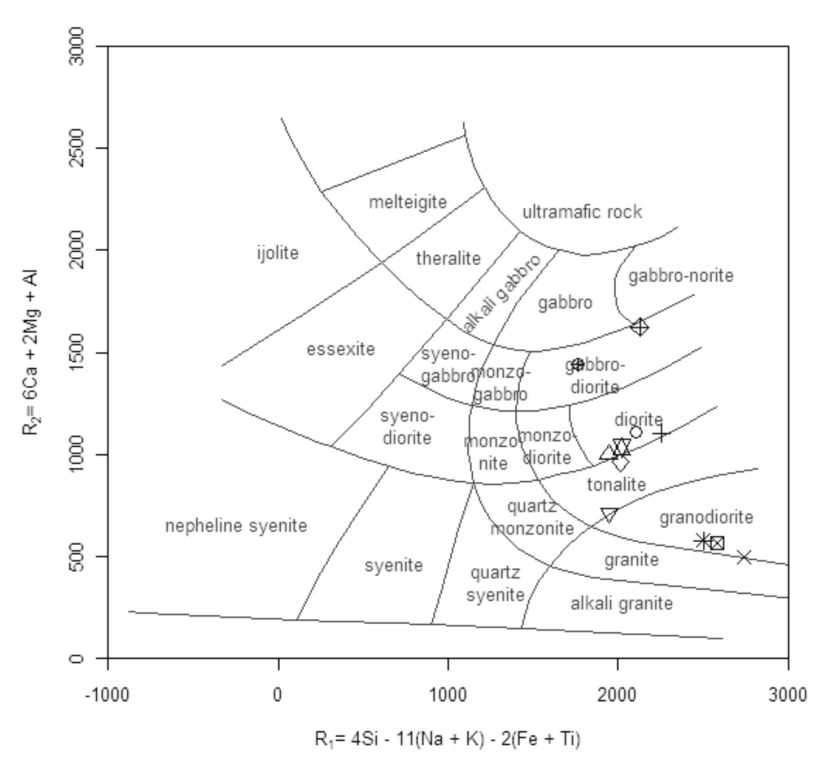

Figure 3: Classification of the study rocks using the parameters R1 and R2 (after De La Roche, 1980), calculated from multication proportions 


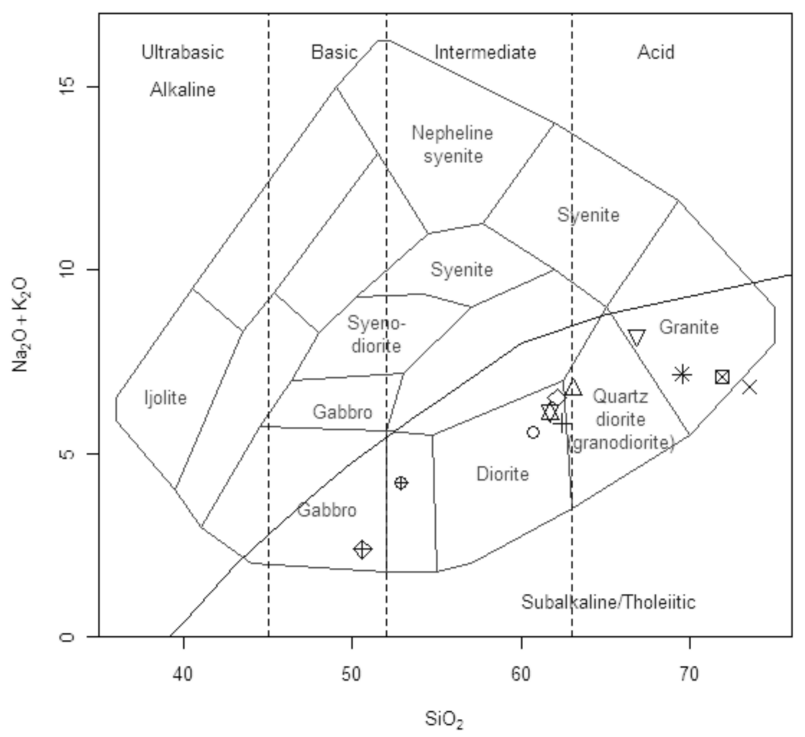

Figure 4: Plot of the rock samples from Sanggau area in the classification diagram of Cox et al., (1979)

The rocks are essentially calc-alkaline on the AFM diagram (Figure 6) of Irvine and Baragar (1971).

\section{Major Element variations}

The $\mathrm{TiO}_{2}$ and $\mathrm{Na}_{2} \mathrm{O}+\mathrm{K}_{2} \mathrm{O}$ vs. $\mathrm{SiO}_{2}$ plots (Figure 7) clearly discriminate samples contain variation correlation of oxide elements. As noted that, the samples show little variation in $\mathrm{SiO}_{2}$ and while $\mathrm{FeO}_{t}, \mathrm{TiO}_{2}, \mathrm{MgO}$ and $\mathrm{CaO}$ exhibit negative correlation, $\mathrm{P}_{2} \mathrm{O}_{5}$ and $\mathrm{K}_{2} \mathrm{O}$ show positive correlation with increasing in $\mathrm{SiO}_{2}$. A lack of iron-enrichment in the basement rocks with fractionation suggests their calc alkaline nature (Miyashiro 1977; Irvine and Baragar, 1971)

\section{Petrogenesis and Tectonic Setting of Origin}

For assessing the petrogenetic association, the basement analyses are plotted in $\mathrm{ACNK}$ vs. $\mathrm{ANK}$ (where $\mathrm{ACNK}=$ molar $\mathrm{Al}_{2} \mathrm{O}_{3} /\left[\mathrm{CaO}+\mathrm{Na}_{2} \mathrm{O}+\mathrm{K}_{2} \mathrm{O}\right]$, and $\mathrm{ANK}=$ molar $\left.\mathrm{Al}_{2} \mathrm{O}_{3} /\left[\mathrm{Na}_{2} \mathrm{O}+\mathrm{K}_{2} \mathrm{O}\right]\right)$ diagram of Maniar and Piccoli (1989).

The analyzed samples of basement rocks show metaluminous character (Figure 8). The AFM diagram is most commonly used to distin-

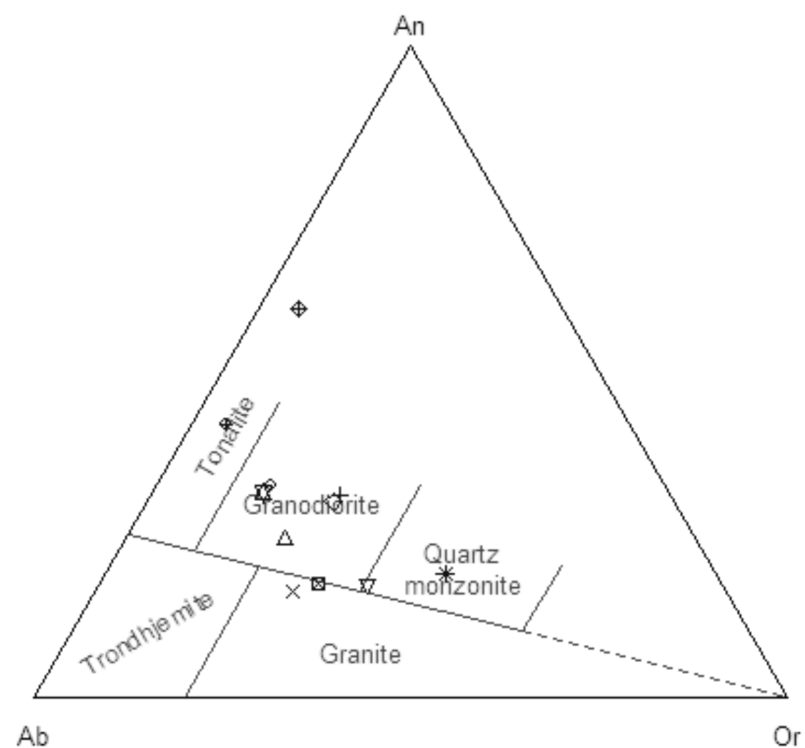

Figure 5: Ab-An-Or ternary plot classifying the silicic rocks ( $>10 \%$ modal quartz) of the rocks. Fields are after O'Connor (1965) with modification of Barker (1979)

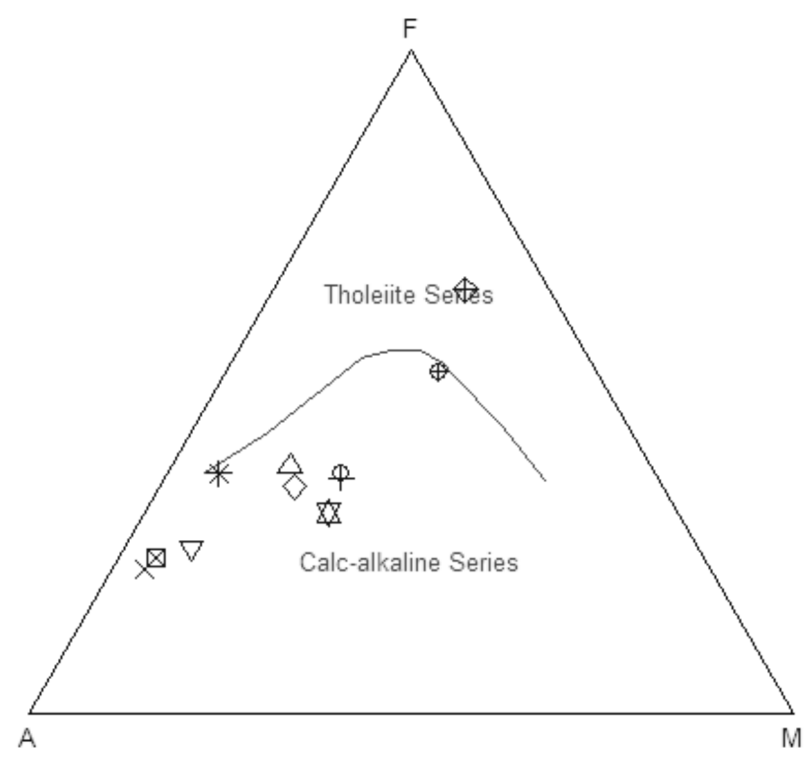

Figure 6: AFM diagram showing the calcalkaline character of the sample alalyzsis (Irvine \& Baragar, 1971) 

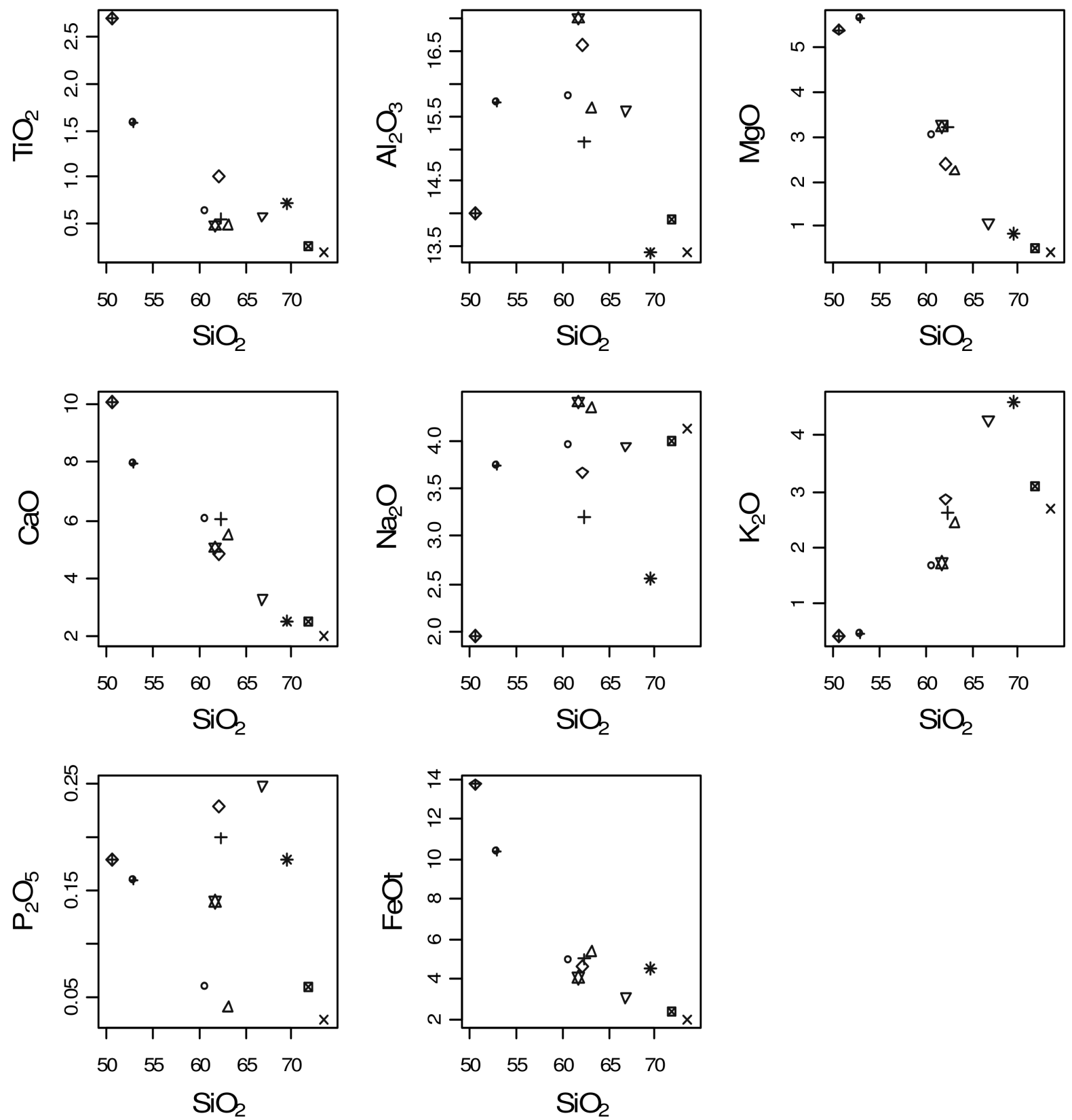

Figure 7: Binary plots showing behavior of major elements against $\mathrm{SiO}_{2}$ in granitoid rocks from Sanggau area 


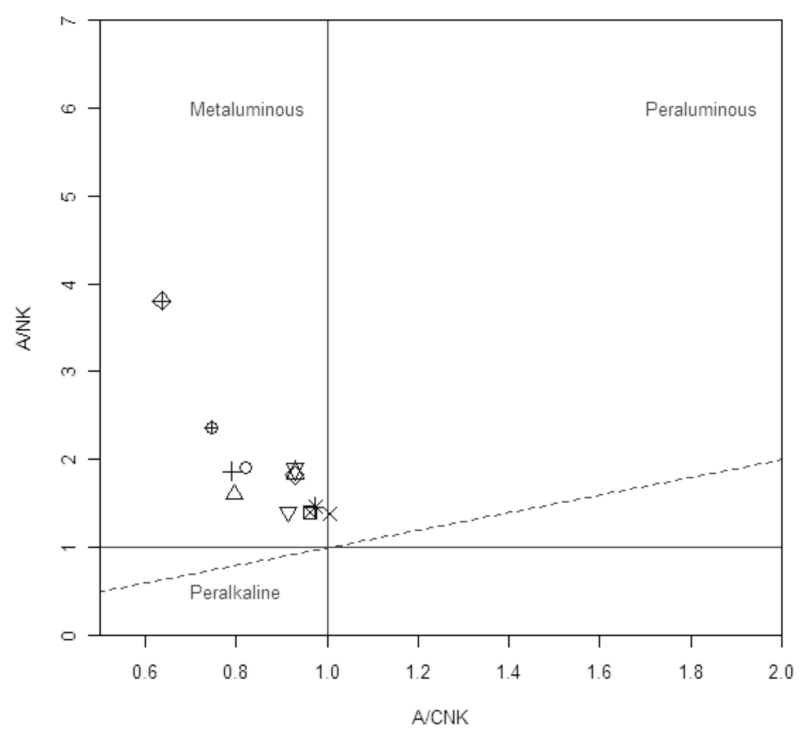

Figure 8: Classification of granitoid rocks from Sanggau area on the basic of Shand's molar indices, $\mathrm{ACNK}=\mathrm{Al}_{2} \mathrm{O}_{3}\left(\mathrm{CaO}+\mathrm{Na}_{2} \mathrm{O}+\mathrm{K}_{2} \mathrm{O}\right)$ and $\mathrm{ANK}=\mathrm{Al}_{2} \mathrm{O}_{3}\left(\mathrm{Na}_{3} \mathrm{O}+\mathrm{K}_{2} \mathrm{O}\right)$ (after Maniar and Piccoli,1989)

guish between tholeiitic and calc-alkaline differentiation trends in the sub-alkaline magma series. Miyashiro (1974) presented dividing lines separating the rocks of the calc-alkaline series and tholeiitic series. On this diagram (Figure 9), the analyses plots in the field of most are calc-alkaline series. It was concluded that the basement rocks evolved from magma of calc-alkaline affinity. The calc-alkaline character of the basement rocks is further substantiated by their metaluminous character revealed by their high ANK ratio (1.2-3.9) relative to ACNK (0.62-1.0).

Whereas the major element chemistry of the basement rocks is of limited usage, restricted to classification, nomenclature, and assessment of their petrological association, some sample with full set of trace elements is of greater help, in determining the nature of the source material, and in deciphering the tectonic setting of origin. Pearce et al., (1984) devised a variety of diagrams based on incompatible trace elements for distinguishing within-plate, collisional, volcanic arc and oceanic-ridge granites. The volcanic arc origin for the basement sample is substantiated by $\mathrm{Rb}$ vs. $\mathrm{Y}+\mathrm{Nb}$ plot of Pearce et al., (1984) in Figure 10. The metaluminous nature

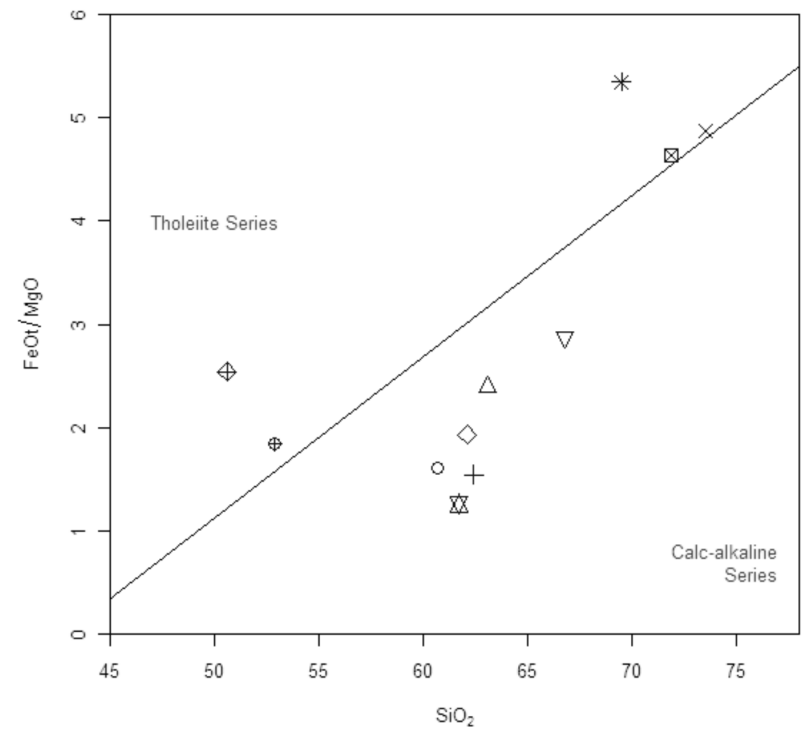

Figure 9: Samples showing the affinity of calcalkaline and tholeiite series of the granitoid rock analyses after Miyashiro (1974).

of Sanggau is evident from major cation parameters of Debon and Le Fort (1983), which essentially consist of biotite + amphibole \pm pyroxene assemblage (Figure 11). The R1-R2 multication factors (De La Roche et al., 1980) classify the samples as granodiorite and quartz monzonite (Figure 5), corresponding to basement rocks formed in pre-plate collision and Sintang Intrusions formed by syn-collision tectonic setting (Figure 12).

The basement rock is compared with granites and granodiorite from type tectonic settings in terms of ocean ridge granite (ORG)- normalized trace element patterns (Figure 13). The rock from Sintang Intrusion has a spiked pattern, which makes it different from all other tectonic settings. However, a lower content of HFSE, negative $\mathrm{Nb}$ anomaly, and not too enriched abundance of LILE suggest a closer match with island arc tholeiites and volcanic arc granites than with the within-plate granites. The basement rock from pre-plate collision and Sintang intrusion is from syn-collision in terms of trace element spider diagram. 


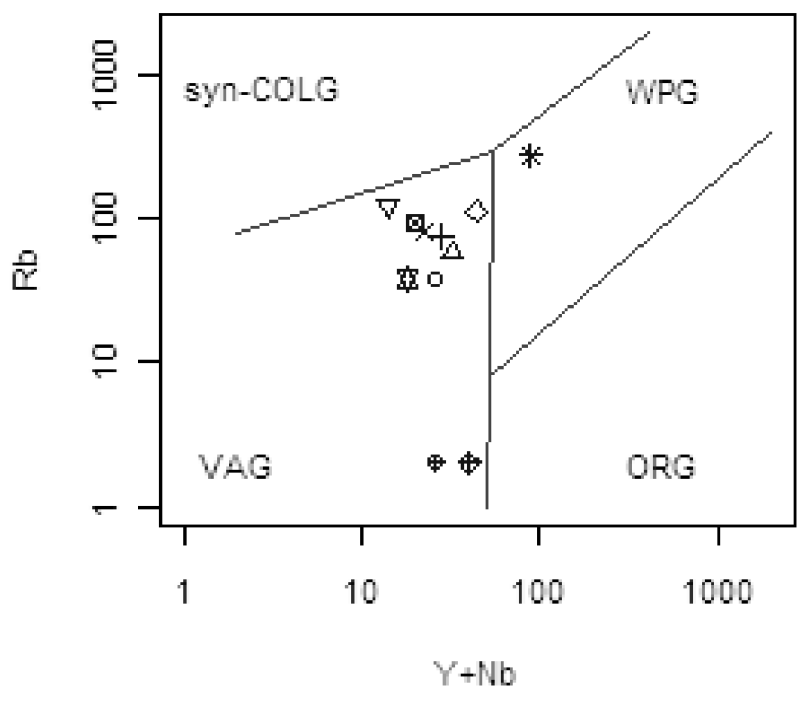

Figure 10: $\mathrm{Rb}$ vs. $\mathrm{Y}+\mathrm{Nb}$ discriminant of the rock analysis of the samples. Syn-collisional granite (syn-COLG), volcanic arc granite (VAG), within plate granite (WPG) and ocean ridge granite (ORG) are after Pearce et al. (1984)

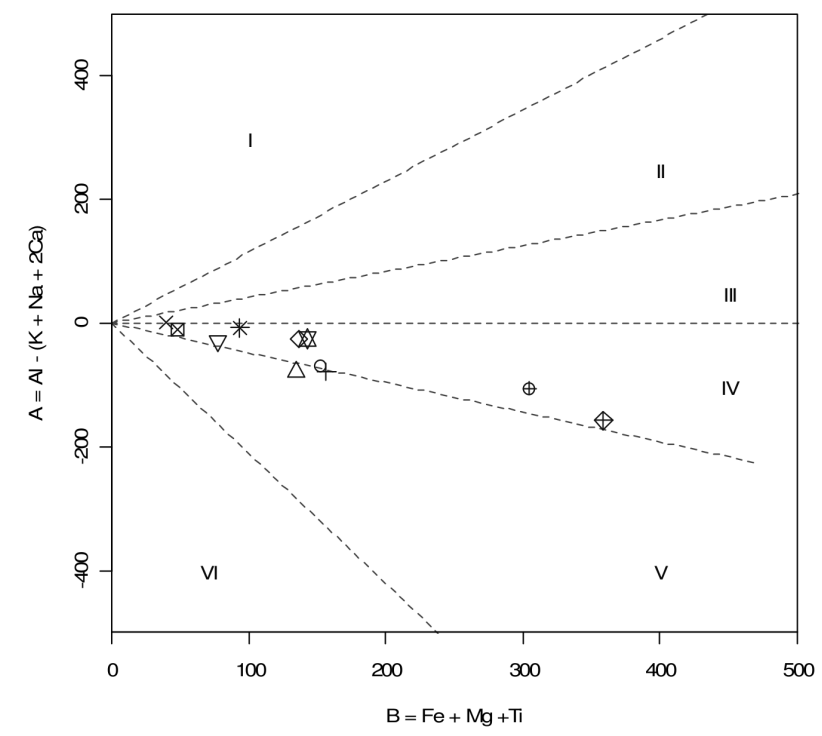

Figure 11: A-B diagram (Debon and Le Fort, 1983) plotted for granitoid in present. Each of its six sectors, numbered from I to VI, corresponds to a specific mineral assemblage. I, II and III are peraluminous sectors, where I: muscovite>biotite (by volume); II: biotite>muscovite; III: biotite (usually alone, at times with a few amphiboles); IV, V and VI are metaluminous sectors, where IV: biotite+ amphibole \pm pyroxene; V:clinopyroxene \pm amphibole \pm biotite; VI: unusual rocks (e.g., carbonatites)

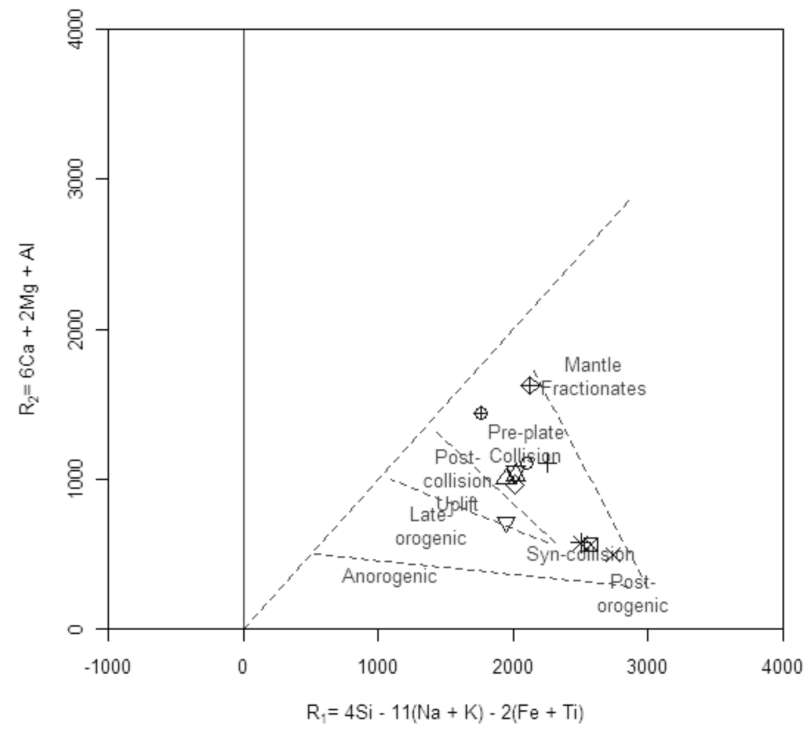

Figure 12: Classification and nomenclature of granitoid rocks using the parameters R1 and R2 of De La Roche et al., (1980), calculated from multication proportions

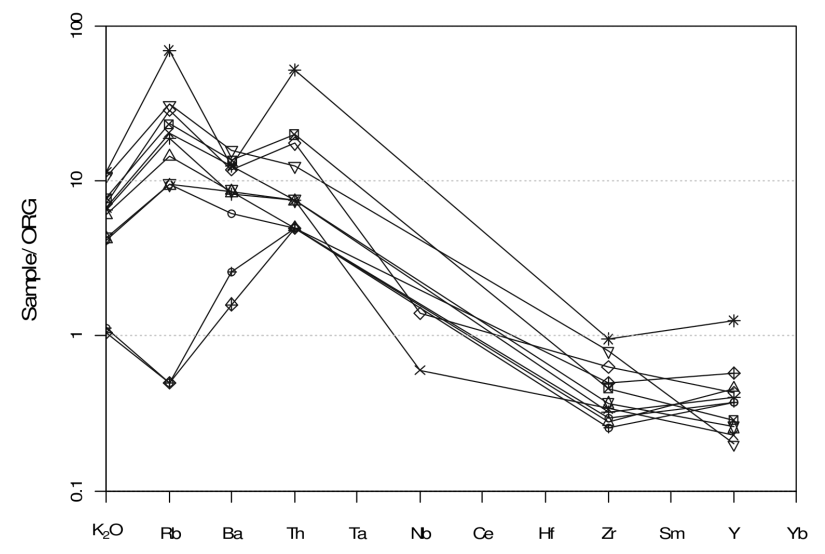

Figure 13: Comparison of the eight representative samples from Sanggau area (ocean ridge granite value after Pearce et al., 1984) 


\section{Adakite Geochemistry}

The term adakite comes from island of Adak (Aleutian Island, Alasaka) and was originally defined to describe Cenozoic ( $<25 \mathrm{Ma})$ arcrelated volcanic rocks with a number of geochemical characteristics, including $\mathrm{SiO}_{2} \geq 56$ wt. $\%, \mathrm{Al}_{2} \mathrm{O}_{3} \geq 5$ wt. $\%, 3$ wt. $\% \leq \mathrm{MgO} \leq 6$ wt. $\%$, $\mathrm{Y} \leq 18 \mathrm{ppm}, \mathrm{Sr} \geq 400 \mathrm{ppm}$ (Defant and Drummond, 1990). Contrary to normal, arc-related tholeiitic and calc-alkaline rocks that originate in the mantle wedge and later evolve by crystal fractionation or other processes, the adakitic rocks are derived from direct partial melting of a subducting slab (Defant and Drummond, 1990). These authors related the magma generation to the melting of hot, young $(<25 \mathrm{Ma})$ subducting lithosphere. Numerical and petrological models (Peacock et al., 1994) restrict the process to even younger subducting lithosphere ( $<5 \mathrm{Ma})$ at typically $60-80 \mathrm{~km}$ depth.

A graph of $\mathrm{Sr} / \mathrm{Y}$ vs. Y (Figure 14) emphasizes the difference between basement granitoid rocks and Sintang Intrusive rock. Samples from Sintang Intrusive rocks are within adakite field. Partial melting of source would generate melting curves that pass through the adakite field toward high Sr/Y but low Y. According to adakite geochemistry and trace element interpretation, Sintang Intrusive rocks may come from post subduction tectonic setting.

According to dating, in the correspond area, younger magmatic products of $28.1 \pm 0.4 \mathrm{Ma}$ indicate the chemical characters of adakitic magmatism. These all of the above data show that during Oligo-Miocene time in Sintang areas, the previous magmatic system giving the products have been introduced by the back-arc magmatic system. The occurrence of Sintang adakites then may correlate rather to the collision than to the subducted young oceanic plate, hence the collision of Luconian continental block to Kalimantan (Priadi, 2010).

\section{Discussion and Conclusion}

On the basis of geochemistry, the granite rocks are considered to be product of crystallization differentiation of a calc-alkaline magma with pyroxene, biotite and amphibole playing

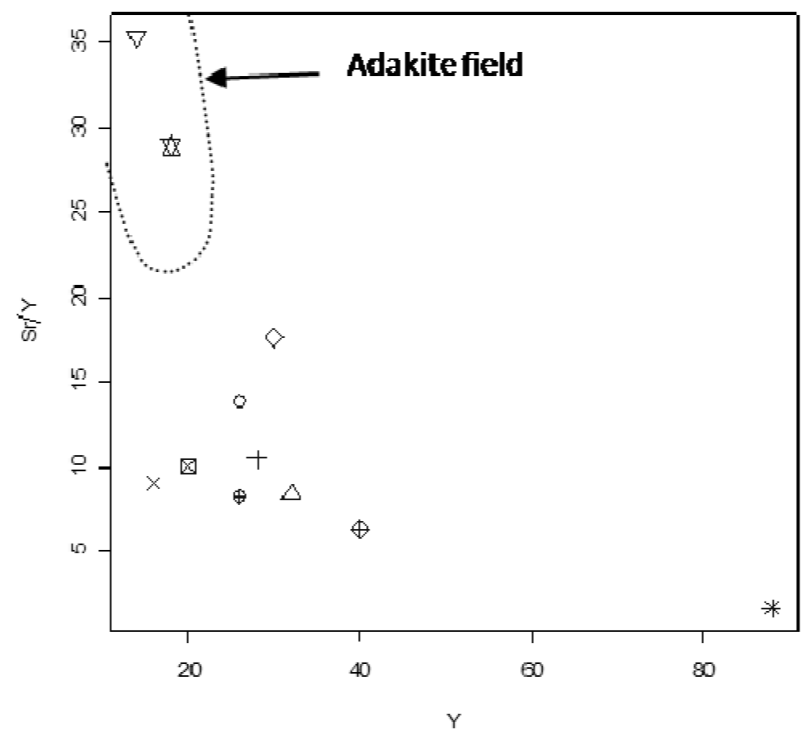

Figure 14: Y vs. Sr/Y binary diagram showing adakite field of the analyses

a major role in fractionation history of granites. The trace element geochemistry of samples collected from the basement is reflective of magmas typical of island arcs. In conclusion, the basement of granite and granodiorite are a segment of island arc that were happened the Sintang Intrusion as post subduction or syncollision tectonic setting.

\section{Acknowledgements}

The author is very grateful to Dr. Lucas Donny Setijadji for his providing and allowing using the data and his kind guidance and suggestion for academic support, as well as AUN/SEEDNet (JICA), Japan International Co-operation Agency, for financially support to process this research work.

\section{References}

Amiruddin (1989) Preliminary study of the granitic rocks of west Kalimantan, Indonesia. MSc Thesis, Department of Geology, University of Wollongong, Australia.

Cox, K.G., Bell, J.D., and Pankhurst, R.J. (1979) The interpretation of igneous rocks. George Allen and Unwin, London.

Debon, F., and Le Fort, P. (1983) A chemicalmineralogical classification of common plutonic 
rocks and association. Earth Sciences. 73. 135149.

De La Roche, H., et al. (1980) A classification of volcanic and plutonic rocks using R1-R2 diagrams and major element analyses- its relationship and current nomenclature. Chemical Geology, 29, 193210.

Defant, M.J., and Drummond, M.S. (1990) Derivation of some modern arc magmas by melting of young subducted lithosphere: Nature, 347, 662665.

Doutche, H.F. (1992) Aspects of the structural histories of the sedimentary basins of East, Central and West Kalimantan and their margins. BMR journal of Australian Geology and Geophysics, 13(3), 237-250.

Irvine, T.N., and Baragar, W.R.A. (1971) A guide to the chemical classification of the common volcanic rocks. Canadian Journal of Earth Sciences, 8, 523-548.

Maniar, P.D., and Piccoli, D.R. (1989) Tectonic discrimination of granitoids. Geological Society of America, Abst. Prog. 11, 468.

Miyashiro, A. (1974) Volcanic rock series in island arc and active continental margins. American Journal of Science, 274, 321-355.
Miyashiro, A. (1977) Subduction zone ophiolites and island arc ophiolites. (S.K. Saxena and Bhattachargi, S, Eds.). Energetics of geological processes. Springer-Verlag (NY).

O'Connor, J.T. (1965) A classification of igneous rocks, based on quartz and feldspar ratios, USGS Prof. Paper, 525-B, 79-84.

Peacock, S.M., Rushmer, T., Thompson, A.B. (1994) Partial melting of subducting oceanic crust. Earth and Planetary Science Letters, 121, 227-244.

Pearce, J.A., Harris, N.B.W., and Tindle, A.G. (1984) Trace element discrimination diagrams for the tectonic interpretation of granitic rocks. Journal of Petrology, 25, 956-983.

Priadi, P. (2010) Kalimantan Coal and Mineral Resources, in Proceeding MEGI-IAGI. 187-190.

Supriatna, S., Margono, U., Sutrisno, Keyser, F. de., Langford, R.P., Trail, D.S. (1993) Geology of the Sanggau Sheet area, Kalimantan. Geological Research and Development Centre.

William, P.R., Johnston, C.R., Almond, R.A., \& Simamora, W.H. (1988) Northwest Borneo: a lateCretaceous to early-Tertiary Accretionary complex. Tectonophysics, 149, 279-297. 